\title{
Nitrogen and Carbon Cycling in a Grassland Community Ecosystem as Affected by Elevated Atmospheric $\mathrm{CO}_{2}$
}

\author{
H. A. Torbert, ${ }^{1}$ H. W. Polley, ${ }^{2}$ and H. B. Johnson ${ }^{2}$ \\ ${ }^{1}$ National Soil Dynamics Laboratory, USDA Agricultural Research Service, 411 S. Donahue, Auburn, AL 36832, USA \\ ${ }^{2}$ Grassland Soil and Water Research Laboratory, USDA Agricultural Research Service, 808 E Blackland Road, Temple, \\ TX 76502, USA
}

Correspondence should be addressed to H. A. Torbert, allen.torbert@ars.usda.gov

Received 4 January 2012; Accepted 7 February 2012

Academic Editor: Dexter B. Watts

Copyright (C) 2012 H. A. Torbert et al. This is an open access article distributed under the Creative Commons Attribution License, which permits unrestricted use, distribution, and reproduction in any medium, provided the original work is properly cited.

\begin{abstract}
Increasing global atmospheric carbon dioxide $\left(\mathrm{CO}_{2}\right)$ concentration has led to concerns regarding its potential effects on terrestrial ecosystems and the long-term storage of carbon $(\mathrm{C})$ and nitrogen $(\mathrm{N})$ in soil. This study examined responses to elevated $\mathrm{CO}_{2}$ in a grass ecosystem invaded with a leguminous shrub Acacia farnesiana (L.) Willd (Huisache). Seedlings of Acacia along with grass species were grown for 13 months at $\mathrm{CO}_{2}$ concentrations of 385 (ambient), 690, and $980 \mu \mathrm{mol} \mathrm{mol}^{-1}$. Elevated $\mathrm{CO}_{2}$ increased both $\mathrm{C}$ and $\mathrm{N}$ inputs from plant growth which would result in higher soil $\mathrm{C}$ from litter fall, root turnover, and excretions. Results from the incubation indicated an initial (20 days) decrease in $\mathrm{N}$ mineralization which resulted in no change in $\mathrm{C}$ mineralization. However, after 40 and 60 days, an increase in both $\mathrm{C}$ and $\mathrm{N}$ mineralization was observed. These increases would indicate that increases in soil C storage may not occur in grass ecosystems that are invaded with Acacia over the long term.
\end{abstract}

\section{Introduction}

The rise of $\mathrm{CO}_{2}$ in the atmosphere is well documented [1]; what has not been documented are the sinks for this $\mathrm{C}$, with an estimated unknown sink of $1.4 \times 10^{15} \mathrm{~g} \mathrm{Cyr}^{-1}$ arising from the global C balance [2]. Carbon dioxide is a prime chemical input to the metabolism of higher plants and has a major role in governing plant-water relations and water use efficiency. The increased growth of most plants under higher levels of $\mathrm{CO}_{2}$ [3-6] has prompted recent speculation on the ability of terrestrial ecosystems to sequester C [7]. However, the fate of $\mathrm{C}$ within ecosystems is affected by a biological chain of events which includes competition between plants. The ability of terrestrial ecosystems to sequester $\mathrm{C}$ will depend on the cycling of $\mathrm{C}$ among the various biomass and soil $\mathrm{C}$ pools and on the residence time of $\mathrm{C}$ in these pools.

The rate of $\mathrm{C}$ mineralization during decomposition of residue derived from plants grown under elevated $\mathrm{CO}_{2}$ has not been resolved. It has been theorized that the commonly observed increase in plant $\mathrm{C}: \mathrm{N}$ ratio under elevated $\mathrm{CO}_{2}$ could lead to slower residue decomposition resulting in increased soil C storage and reduction in available $\mathrm{N}$ for plant production [8]. However, slower decomposition of leaf litter due to elevated $\mathrm{CO}_{2}$ is not supported by the literature on litter quality [9]. Others have suggested that increased biomass might enhance microbial activity, resulting in a "priming effect" thereby leading to no increase in C storage [10]. Alternatively, microbial preference for easily decomposable plant material produced under $\mathrm{CO}_{2}$-enriched conditions could reduce the turnover of more resistant organic material, thereby increasing soil C $[11,12]$. Observations from field and laboratory studies indicate that with elevated atmospheric $\mathrm{CO}_{2}, \mathrm{~N}$ may limit the rate of plant residue decomposition and slow the release of $\mathrm{N}$ from decomposing plant material [13]. This indicates that understanding $\mathrm{N}$ cycling as affected by elevated $\mathrm{CO}_{2}$ is fundamental to understanding the potential for soil C storage on a global scale.

It has also been speculated that changes in elevated $\mathrm{CO}_{2}$ could impact the competitiveness between plant species, especially between native and invasive plant species. A study by Runion et al. [14] indicated that elevated atmospheric $\mathrm{CO}_{2}$ increased biomass production in a longleaf ecosystem compared to ambient $\mathrm{CO}_{2}$ conditions. However, close examination of biomass data for each species in this plant 
community indicated that only longleaf pine showed a significant positive response to elevated atmospheric $\mathrm{CO}_{2}$ treatment. In grasslands, invasion by woody legumes such as Acacia can alter hydrology, nutrient accumulation and cycling, and $\mathrm{C}$ sequestration. The rate and magnitude of these changes are likely to be sensitive to the effects of atmospheric $\mathrm{CO}_{2}$ enrichment on growth and water and $\mathrm{N}$ dynamics of leguminous shrubs. Polley et al. [15] indicated that, at the highest $\mathrm{CO}_{2}$ concentration studied, biomass production of grass-tree communities increased more than 2.5 -fold as a result of increased leaf photosynthetic rates, leaf area, and $\mathrm{N}_{2}$ fixation.

Previous research, considering the effect of elevated $\mathrm{CO}_{2}$ on the decomposition of individual plant parts and monoculture plant systems has indicated that increased soil C storage could occur $[16,17]$. However, these past studies did not consider the impact of increased biomass input and the changes in soil brought about by differing responses of plant species. The objective of this study was to determine the impact of atmospheric $\mathrm{CO}_{2}$ enrichment on potential soil $\mathrm{C}$ and $\mathrm{N}$ mineralization in a grassland community.

\section{Materials and Methods}

A study on the effects of elevated $\mathrm{CO}_{2}$ concentrations on the productivity, water use, and $\mathrm{N}$ dynamics of the grassland invader Acacia farnesiana (L.) Willd (Huisache) was conducted by Polley et al. [15]. To study the impact of atmospheric $\mathrm{CO}_{2}$ enrichment on potential soil $\mathrm{C}$ and $\mathrm{N}$ mineralization within a grassland community, an incubation study was conducted on soil collected from this study. Descriptions of the study site and the model ecosystem have been previously reported [15]. Briefly, seeds of Acacia were planted in fine sandy loam soil (Udic Paleustalfs [18], in wheeled, 380 -liter containers $(0.9 \mathrm{~m}$ deep and $0.65 \mathrm{~m}$ on each side) ). Three Acacia plants were established in each container.

Three individuals each of the $\mathrm{C}_{3}$ grass Stipa leucotricha Trin. and Rupr. (Texas winter grass) and the $\mathrm{C}_{4}$ grass Schizachyrium scoparium (Michx.) Nash. (little bluestem) were also established from tillers in each container to provide a competitive environment for Acacia growth. Three 380-liter containers of the species mix were maintained for 13 months at average $\mathrm{CO}_{2}$ concentrations of 385 (ambient), 690, or $980 \mu \mathrm{mol} \mathrm{mol}^{-1}$ in air-conditioned greenhouse bays.

Carbon dioxide gas was injected into the greenhouse bays as necessary to maintain the desired concentrations. The $\mathrm{CO}_{2}$ concentration and dewpoint temperature of air in each bay were measured at $4 \mathrm{~min}$ intervals with an infrared gas analyzer (Model 6262, Li-Cor, Inc., Lincoln, NE). The $\mathrm{CO}_{2}$ readings were corrected for atmospheric pressure using a pressure indicator (Model DPI 260, Druck Inc., New Fairfield, CT). The $\mathrm{CO}_{2}$ concentration of air averaged 385, 690 , and $980 \mu \mathrm{mol} \mathrm{mol}^{-1}$ for the three $\mathrm{CO}_{2}$ treatments. Air temperature was measured with $25 \mathrm{~mm}$ diameter thermocouples, and bay temperature was changed seasonally to approximate outdoor temperature by manually adjusting thermostatic controls.

At the conclusion of the study (13 months), soil samples were collected from $0-20,20-50$, and $50-80 \mathrm{~cm}$ depth increments for use in the incubation study. Soil subsamples were dried $\left(55^{\circ} \mathrm{C}\right)$ and ground to pass a $0.15 \mathrm{~mm}$ sieve. Soil inorganic $\mathrm{N}\left(\mathrm{NO}_{2}-\mathrm{N}+\mathrm{NO}_{3}-\mathrm{N}\right.$ and $\left.\mathrm{NH}_{4}-\mathrm{N}\right)$ was extracted with $2 \mathrm{M} \mathrm{KCl}$ and measured by standard colorimetric procedures using a Technicon Autoanalyzer 3 (Bran + Luebbe, Buffalo Grove, IL). Soil subsamples were weighed ( $25 \mathrm{~g}$ dry weight basis) and placed in plastic containers. Deionized water was added to adjust soil water content to an equivalent of $-20 \mathrm{kPa}$ at a bulk density of $1.3 \mathrm{mg} \mathrm{m}^{-3}$. The containers were placed in sealed glass mason jars with $10 \mathrm{~mL}$ of water for humidity control; each jar also had a vial containing $10 \mathrm{~mL}$ of $1 \mathrm{M} \mathrm{NaOH}$ which functioned as a $\mathrm{CO}_{2}$ trap. The jars were incubated in the dark at $25^{\circ} \mathrm{C}$ and removed after 20 and 60 days for inorganic $\mathrm{N}$ determination. Carbon dioxide in the $\mathrm{NaOH}$ traps was determined by titrating the excess base with $1 \mathrm{M} \mathrm{HCl}$ in the presence of $\mathrm{BaCl}_{2}$ after 20,40 , and 60 days. Potential $\mathrm{C}$ mineralization was the difference between $\mathrm{CO}_{2}-\mathrm{C}$ captured in sample traps and in blanks. Potential N mineralization was the difference between final and initial inorganic $\mathrm{N}$ contents. The $\mathrm{C}$ mineralization divided by total C (initial soil C concentration) was used to calculate C turnover. Statistical analyses were performed using the mixed procedure of SAS [19], and means were separated using least significant difference at an a priori 0.10 probability level.

\section{Results and Discussion}

Increasing atmospheric $\mathrm{CO}_{2}$ concentration to $980 \mu \mathrm{mol}$ $\mathrm{mol}^{-1}$ increased biomass production of the woody legume Acacia more than 2.5-fold during the initial year of growth due to increased leaf photosynthetic rates, leaf area, and $\mathrm{N}_{2}$ fixation [15]. The increase in biomass at elevated $\mathrm{CO}_{2}$ required no more water than was consumed by the shrubs grown near ambient $\mathrm{CO}_{2}$ concentration. As a result, apparent water use efficiency and biomass production increased by similar relative amounts. Elevated $\mathrm{CO}_{2}$ greatly increased $\mathrm{N}_{2}$ fixation by Acacia, with the total $\mathrm{N}$ fixed per plant at the highest $\mathrm{CO}_{2}$ concentration being 1.5 times greater compared to ambient $\mathrm{CO}_{2}$ conditions. This positive effect of $\mathrm{CO}_{2}$ on $\mathrm{N}_{2}$ fixation by Acacia during its initial year of growth is generally consistent with that reported for woody legumes $[20,21]$. Nitrogen fixation promoted by elevated $\mathrm{CO}_{2}$ would be expected to provide additional $\mathrm{N}$ to a grassland ecosystem due to the $\mathrm{N}$ addition to the soil following litter fall, root turnover, and exudation. These are important factors by which increasing atmospheric $\mathrm{CO}_{2}$ concentration can modify the impact of woody legumes on grasslands. Studies have shown that plant matter grown under elevated $\mathrm{CO}_{2}$ can greatly impact $\mathrm{N}$ mineralization $[16,17]$. This incubation study was conducted to determine the impact of the elevated $\mathrm{CO}_{2}$ concentration on soil $\mathrm{N}$ mineralization in a grassland system.

After 20 days of incubation of the $0-20 \mathrm{~cm}$ depth soil, $\mathrm{N}$ mineralization was significantly reduced by elevated $\mathrm{CO}_{2}$, with $\mathrm{N}$ mineralization being $95 \%$ higher at ambient $\mathrm{CO}_{2}$ compared to the $980 \mu \mathrm{mol} \mathrm{mol}^{-1}$ treatment level (Table 1). During this same measuring period, soil $\mathrm{C}$ mineralization and $\mathrm{C}$ turnover were not significantly impacted. This indicated that changes under elevated $\mathrm{CO}_{2}$ initially reduced $\mathrm{N}$ 
TABLE 1: Effect of atmospheric $\mathrm{CO}_{2}$ concentration on soil $\mathrm{N}$ mineralization during a 60 -day soil incubation at three soil depth increments ${ }^{\dagger}$.

\begin{tabular}{lccccc}
\hline & & $0-20$ days & \multicolumn{3}{c}{$0-60$ days } \\
$\mathrm{CO}_{2}$ level & $0-20 \mathrm{~cm}$ & $20-50 \mathrm{~cm}$ & $50-80 \mathrm{~cm}$ & $\begin{array}{c}\text { Depth } \\
\left(\mu \mathrm{mol} \mathrm{mol}^{-1}\right)\end{array}$ \\
\hline 385 & $6.86 \mathrm{a}$ & $1.91 \mathrm{a}$ & $1.37 \mathrm{a}$ & $7.51 \mathrm{a}$ & $4.01 \mathrm{a}$ \\
690 & $2.91 \mathrm{~b}$ & $0.59 \mathrm{a}$ & $0.69 \mathrm{a}$ & $7.85 \mathrm{~b}$ & $3.86 \mathrm{~cm}$ \\
980 & $3.52 \mathrm{c}$ & $2.91 \mathrm{a}$ & $0.46 \mathrm{a}$ & $10.04 \mathrm{c}$ & $3.54 \mathrm{a}$ \\
\hline
\end{tabular}

${ }^{\dagger}$ Values represent means of three replications. Means within a column for each sampling date followed by the same letter do not differ significantly $(\alpha=0.1)$.

mineralization rates. While greater plant inputs were entering the system, with greater total $\mathrm{N}$ from the $\mathrm{N}_{2}$ fixation, the quality of the plant residues were such that $\mathrm{N}$ mineralization was being limited. This reduction in inorganic $\mathrm{N}$ in soil solution in turn limited $\mathrm{C}$ mineralization, resulting in no difference in $\mathrm{C}$ respiration or $\mathrm{C}$ turnover at the 20-day sampling period (Tables 2 and 3). This is consistent with studies by Torbert et al. [17] which indicated that the impact of elevated atmospheric $\mathrm{CO}_{2}$ concentration on plant residue quality may be more important than the impact on plant residue quantity in determining $\mathrm{C}$ cycling in soil. They observed that the potential effect of elevated atmospheric $\mathrm{CO}_{2}$ concentration on $\mathrm{C}$ storage in agroecosystems will be dependent on the crop species grown, where $\mathrm{N}$ cycling within the plant/soil system would likely be the controlling factor for $\mathrm{C}$ storage in these systems. Likewise, these results agree with work from a free-air $\mathrm{CO}_{2}$ enrichment (FACE) study utilizing cotton (Gossypium hirsutum L.) [22] and wheat (Triticum aestivum L.) [23], which provided evidence for increased soil $\mathrm{C}$ storage even though differences between the two species (cotton and wheat) were noted.

However, unlike the agroecosystem studies, limitations to $\mathrm{N}$ mineralization did not persist in this grass ecosystem with Acacia. At the 40-day sampling period, a significant increase was observed with $\mathrm{C}$ mineralization as atmospheric $\mathrm{CO}_{2}$ was increased (Table 2). Likewise, an increase in the level of $\mathrm{C}$ turnover was observed with increasing atmospheric $\mathrm{CO}_{2} \mathrm{lev}$ els. At the 60-day measurement period, $\mathrm{C}$ mineralization was also significantly increased at the $980 \mu \mathrm{mol} \mathrm{mol}^{-1}$ compared to the ambient level as was $\mathrm{C}$ turnover (Tables 2 and 3 ). The C mineralization for the $980 \mu \mathrm{mol} \mathrm{mol}^{-1}$ treatment was $98 \%$ higher than for the ambient treatment. At this sampling period, unlike the 20-day period, a significant increase in $\mathrm{N}$ mineralization was also observed (Table 1). This indicated that after 60 days, $\mathrm{N}$ was no longer limiting microbial decomposition of plant material. Since increased biomass inputs into the soil system were observed in this study [15] and the limitations due to $\mathrm{N}$ were no longer impacting the decomposition processes, $\mathrm{C}$ mineralization also increased.

No significant differences were observed for $\mathrm{N}$ mineralization or $C$ mineralization at the $20-50 \mathrm{~cm}$ depth or the $50-80 \mathrm{~cm}$ depth (Tables 1 and 3 ). This indicated that most changes in the soil system can be expected to occur in the top $20 \mathrm{~cm}$ of the soil profile. This is the portion of the soil that would be most impacted from litter fall and could result in movement of $\mathrm{N}$ to grass species from $\mathrm{N}_{2}$ fixation by the
Acacia. While this study included a deep rooted species in the grass ecosystem, the greatest changes in $\mathrm{C}$ and $\mathrm{N}$ cycling occurred in the top of the soil profile where most plant rooting occurs.

It has been theorized that a reduction in $\mathrm{N}$ availability in ecosystems could reduce plant response to elevated $\mathrm{CO}_{2}$ conditions [24-26]. The results from this incubation study indicate that $\mathrm{N}$ mineralization was increased and therefore the potential for $\mathrm{N}$ limitations to reduce plant response to elevated $\mathrm{CO}_{2}$ in this grass ecosystem might not occur. This would indicate that over the long term in a grass ecosystem invaded with woody legumes such as Acacia, $\mathrm{N}$ resources should not be limiting for either microbial decomposition of residues or plant growth in future elevated atmospheric $\mathrm{CO}_{2}$ conditions compared to today's conditions.

In a study to examine responses to elevated $\mathrm{CO}_{2}$ in a typical regenerating longleaf pine-wiregrass community, Torbert et al. [27] reported, as in this study with mixed plant species, an increase in $\mathrm{N}$ mineralization with elevated $\mathrm{CO}_{2}$. At least over the short term in a regenerating longleaf pine system, $\mathrm{N}$ resources should not be limiting for either microbial decomposition of residues or plant growth in future elevated atmospheric $\mathrm{CO}_{2}$ conditions compared to today's conditions. However, elevated $\mathrm{CO}_{2}$ decreased soil $\mathrm{C}$ respiration and $\mathrm{C}$ turnover in the regenerating longleaf pinewiregrass community, indicating long-term $\mathrm{C}$ sequestration would be likely. In the current study with grass species, an actual increase in soil $\mathrm{C}$ mineralization was observed with elevated $\mathrm{CO}_{2}$. This was likely due to the large input of $\mathrm{N}$ due to increase in $\mathrm{N}_{2}$ fixation by the Acacia into the plant/soil system. Polley et al. [15] reported total $\mathrm{N}$ accretion by Acacia increased with each increase in $\mathrm{CO}_{2}$ concentration: $55 \%$ from 385 to $690 \mu \mathrm{mol} \mathrm{mol}^{-1} \mathrm{CO}_{2}$, and another $29 \%$ from 690 to $980 \mu \mathrm{mol} \mathrm{mol}^{-1} \mathrm{CO}_{2}$. The increased $\mathrm{C}$ mineralization indicated that soil $\mathrm{C}$ levels in the elevated $\mathrm{CO}_{2}$ are being reduced compared to the ambient treatments.

These findings are in contrast to other research which reported that $\mathrm{C}$ sequestration is likely with increasing atmospheric $\mathrm{CO}_{2}$. Low-N availability of soil frequently limits production on grasslands $[23,24]$ and may also limit the response of net primary production to changes in $\mathrm{CO}_{2}$ concentration. However, with the Acacia included in the grass ecosystem, $\mathrm{CO}_{2}$ enrichment caused large $\mathrm{N}$ inputs into the soil system and large increases in biomass (a 2.5-fold increase during the initial year of growth, [15]). Although $\mathrm{C}$ inputs to soil increased, $\mathrm{C}$ mineralization also increased. 
TABLE 2: Effect of atmospheric $\mathrm{CO}_{2}$ concentration on soil $\mathrm{C}$ mineralization during a 60 -day soil incubation at three soil depth increments ${ }^{\dagger}$.

\begin{tabular}{|c|c|c|c|c|c|c|c|c|c|}
\hline \multirow{3}{*}{$\begin{array}{l}\mathrm{CO}_{2} \text { level } \\
\left(\mu \mathrm{mol} \mathrm{mol}^{-1}\right)\end{array}$} & \multicolumn{3}{|c|}{$0-20$ days } & \multicolumn{3}{|c|}{ 20-40 days } & \multicolumn{3}{|c|}{ 40-60 days } \\
\hline & & & & & Depth & & & & \\
\hline & $0-20 \mathrm{~cm}$ & $20-50 \mathrm{~cm}$ & $50-80 \mathrm{~cm}$ & $0-20 \mathrm{~cm}$ & $\begin{array}{l}20-50 \mathrm{~cm} \\
\left(\mathrm{mg} \mathrm{kg}^{-1}\right)\end{array}$ & $50-80 \mathrm{~cm}$ & $0-20 \mathrm{~cm}$ & $20-50 \mathrm{~cm}$ & $50-80 \mathrm{~cm}$ \\
\hline 385 & $57.52 \mathrm{a}$ & $63.94 \mathrm{a}$ & $36.84 \mathrm{a}$ & $59.15 \mathrm{a}$ & $67.15 \mathrm{a}$ & $59.44 \mathrm{a}$ & $210.76 a$ & $263.46 \mathrm{a}$ & $229.40 \mathrm{a}$ \\
\hline 690 & $92.86 \mathrm{a}$ & $41.98 \mathrm{a}$ & $66.94 \mathrm{a}$ & $100.55 \mathrm{~b}$ & $55.80 \mathrm{a}$ & $72.29 \mathrm{a}$ & $199.20 \mathrm{~b}$ & $217.40 \mathrm{a}$ & $246.32 \mathrm{a}$ \\
\hline 980 & $87.93 \mathrm{a}$ & $70.15 \mathrm{a}$ & $34.26 \mathrm{a}$ & $124.98 \mathrm{c}$ & $42.52 \mathrm{a}$ & $69.40 \mathrm{a}$ & $417.46 \mathrm{c}$ & $169.43 \mathrm{a}$ & $256.82 \mathrm{a}$ \\
\hline
\end{tabular}

${ }^{\dagger}$ Values represent means of three replications. Means within a column for each sampling date followed by the same letter do not differ significantly $(\alpha=0.1)$.

TABLE 3: Effect of atmospheric $\mathrm{CO}_{2}$ concentration on soil $\mathrm{C}$ turnover during a 60 -day soil incubation at three soil depth increments ${ }^{\dagger}$.

\begin{tabular}{|c|c|c|c|c|c|c|c|c|c|}
\hline \multirow[b]{2}{*}{$\begin{array}{l}\mathrm{CO}_{2} \text { level } \\
\left(\mu \mathrm{mol} \mathrm{mol}^{-1}\right)\end{array}$} & \multicolumn{3}{|c|}{$0-20$ days } & \multicolumn{3}{|c|}{$\begin{array}{c}\text { 20-40 days } \\
\text { Depth }\end{array}$} & \multicolumn{3}{|c|}{ 40-60 days } \\
\hline & $0-20 \mathrm{~cm}$ & $20-50 \mathrm{~cm}$ & $50-80 \mathrm{~cm}$ & $0-20 \mathrm{~cm}$ & $\begin{array}{c}\text { Depth } \\
20-50 \mathrm{~cm} \\
\left(\mathrm{mg} \mathrm{kg}^{-1}\right)\end{array}$ & $50-80 \mathrm{~cm}$ & $0-20 \mathrm{~cm}$ & $20-50 \mathrm{~cm}$ & $50-80 \mathrm{~cm}$ \\
\hline 385 & $1.01 \mathrm{a}$ & $1.12 \mathrm{a}$ & $0.65 \mathrm{a}$ & $0.85 \mathrm{a}$ & $1.18 \mathrm{a}$ & $1.04 \mathrm{a}$ & $3.70 \mathrm{a}$ & $4.62 \mathrm{a}$ & $4.02 \mathrm{a}$ \\
\hline 690 & $1.63 \mathrm{a}$ & $0.74 \mathrm{a}$ & $1.17 \mathrm{a}$ & $1.75 \mathrm{~b}$ & $0.98 \mathrm{a}$ & $1.27 \mathrm{a}$ & $3.49 \mathrm{~b}$ & $3.81 \mathrm{a}$ & $4.32 \mathrm{a}$ \\
\hline 980 & $1.54 \mathrm{a}$ & $1.23 \mathrm{a}$ & $5.34 \mathrm{a}$ & $2.19 c$ & $0.75 \mathrm{a}$ & $1.22 \mathrm{a}$ & $2.19 \mathrm{c}$ & $2.97 \mathrm{a}$ & $4.51 \mathrm{a}$ \\
\hline
\end{tabular}

${ }^{\dagger}$ Values represent means of three replications. Means within a column for each sampling date followed by the same letter do not differ significantly $(\alpha=0.1)$.

The results from this short-term study indicate that $\mathrm{CO}_{2}$ may not increase soil $\mathrm{C}$ storage in this grassland ecosystem. Thus, long-term studies with elevated $\mathrm{CO}_{2}$ will be necessary to clearly determine the impact of Acacia invasion in this grassland ecosystems on soil $\mathrm{C}$ storage.

\section{References}

[1] C. D. Keeling, R. B. Bacastow, A. F. Carter et al., "A three dimensional model of atmospheric $\mathrm{CO}_{2}$ transport based on observed winds: observational data and preliminary analysis," in Aspects of Climate Variability in the Pacific and the Western America, D. H. Peterson, Ed., vol. 55, pp. 165-235, Geophysical Monograph, 1989.

[2] D. Schimel, I. G. Enting, M. Heimann et al., " $\mathrm{CO}_{2}$ and the carbon cycle," in Climate Change 1994, J. T. Houghton, Ed., pp. 35-71, Cambridge University Press, Cambridge, UK, 1995.

[3] B. R. Strain and D. J. Cure, Eds., "Direct effects of increasing carbon dioxide on vegetation," DOE/ER-0238, Office of Energy Research, U.S. Department of Energy, Washington, DC, USA, 1985.

[4] S. A. Prior, H. H. Rogers, G. B. Runion, and J. R. Mauney, "Effects of free-air $\mathrm{CO}_{2}$ enrichment on cotton root growth," Agricultural and Forest Meteorology, vol. 70, no. 1-4, pp. 6986, 1994.

[5] S. H. Wittwer, Food, Climate, and Carbon Dioxide: The Global Environment and World Food Production, CRC Press, Boca Raton, Fla, USA, 1995.

[6] S. G. Pritchard, H. H. Rogers, S. A. Prior, and C. M. Peterson, "Elevated $\mathrm{CO}_{2}$ and plant structure: a review," Global Change Biology, vol. 5, no. 7, pp. 807-837, 1999.

[7] R. M. Gifford, J. L. Lutze, and D. J. Barrett, "Global atmospheric change effects on terrestrial carbon sequestration: exploration with a global C- and N-cycle model (CQUESTN)," Plant and Soil, vol. 187, no. 2, pp. 369-387, 1996.
[8] Y. Luo, B. Su, W. S. Currie et al., "Progressive nitrogen limitation of ecosystem responses to rising atmospheric carbon dioxide," Bioscience, vol. 54, no. 8, pp. 731-739, 2004.

[9] J. Hom, "Global change and forest soils," in The Potential of US Forest Soils to Sequester Carbon and Mitigate the Greenhouse Effect, J. M. Kimble, Ed., pp. 127-134, CRC Press, Boca Raton, Fla, USA, 2002.

[10] M. R. Lamborg, W. F. Hardy, and E. A. Paul, "Microbial effects," in $\mathrm{CO}_{2}$ and Plants: The Response of Plants to Rising Levels of Atmospheric $\mathrm{CO}_{2}$, E. R. Lemon, Ed., pp. 131-176, American Association for the Advancement of Science Selected Symposium, Washington, DC, USA, 1984.

[11] J. Goudriaan and H. E. de Ruiter, "Plant growth in response to $\mathrm{CO}_{2}$ enrichment at two levels of nitrogen and phosphorus supply. 1. Dry matter, leaf area, and development," Netherlands Journal Agriculture Science, vol. 31, pp. 157-169, 1983.

[12] L. J. A. Lekkerkerk, S. C. van de Geijn, and J. A. van Veen, "Effects of elevated atmospheric $\mathrm{CO}_{2}$ levels on the carbon economy of a soil planted with wheat," in Soils and the Greenhouse Effect, A. F. Bouwman, Ed., pp. 423-429, John Wiley \& Sons, New York, NY, USA, 1990.

[13] R. A. Gill, H. W. Polley, H. B. Johnson, L. J. Anderson, H. Maherali, and R. B. Jackson, "Nonlinear grassland responses to past and future atmospheric $\mathrm{CO}_{2}$," Nature, vol. 417, no. 6886, pp. 279-282, 2002.

[14] G. B. Runion, M. A. Davis, S. G. Pritchard et al., "Effects of elevated atmospheric carbon dioxide on biomass and carbon accumulation in a model regenerating longleaf pine community," Journal of Environmental Quality, vol. 35, no. 4, pp. 1478-1486, 2006.

[15] H. W. Polley, H. B. Johnson, and H. S. Mayeux, "Leaf physiology, production, water use, and nitrogen dynamics of the grassland invader Acacia smallii at elevated $\mathrm{CO}_{2}$ concentrations," Tree Physiology, vol. 17, no. 2, pp. 89-96, 1997. 
[16] H. A. Torbert, S. A. Prior, and H. H. Rogers, "Elevated atmospheric carbon dioxide effects on cotton plant residue decomposition," Soil Science Society of America Journal, vol. 59, no. 5, pp. 1321-1328, 1995.

[17] H. A. Torbert, S. A. Prior, H. H. Rogers, and G. B. Runion, "Crop residue decomposition as affected by growth under elevated atmospheric $\mathrm{CO}_{2}$," Soil Science, vol. 163, no. 5, pp. 412419, 1998.

[18] J. W. Huckabee Jr., D. R. Thompson, J. C. Wyrick, and E. G. Paulat, Soil Survey of Bell County, Texas, USDA, Soil Conservation Service, Washington, DC, USA, 1977.

[19] SAS, SAS System for Personal Computers. Release 9.03, SAS, Cary, NC, USA, 2003.

[20] R. B. Thomas, D. D. Richter, H. Ye, P. R. Heine, and B. R. Strain, "Nitrogen dynamics and growth of seedlings of an $\mathrm{N}$-fixing tree (Gliricidia sepium (Jacq.) Walp.) exposed to elevated atmospheric carbon dioxide," Oecologia, vol. 88, no. 3, pp. 415-421, 1991.

[21] C. S. Vogel and P. S. Curtis, "Leaf gas exchange and nitrogen dynamics of $\mathrm{N}_{2}$-fixing, field-grown Alnus glutinosa under elevated atmospheric $\mathrm{CO}_{2}$," Global Change Biology, vol. 1, pp. 55-61, 1995.

[22] C. W. Wood, H. A. Torbert, H. H. Rogers, G. B. Runion, and S. A. Prior, "Free-air $\mathrm{CO}_{2}$ enrichment effects on soil carbon and nitrogen," Agricultural and Forest Meteorology, vol. 70, no. 1-4, pp. 103-116, 1994.

[23] S. A. Prior, H. A. Torbert, G. B. Runion et al., "Free-air $\mathrm{CO}_{2}$ enrichment of wheat: soil carbon and nitrogen dynamics," Journal of Environmental Quality, vol. 26, no. 4, pp. 11611166, 1997.

[24] D. S. Schimel, T. G. F. Kittel, A. K. Knapp, T. R. Seastedt, W. J. Parton, and V. B. Brown, "Physiological interactions along resource gradients in a tallgrass prairie," Ecology, vol. 72, no. 2, pp. 672-684, 1991.

[25] T. R. Seastedt, J. M. Briggs, and D. J. Gibson, "Controls of nitrogen limitation in tallgrass prairie," Oecologia, vol. 87, no. 1, pp. 72-79, 1991.

[26] B. R. Strain and F. A. Bazzaz, "Terrestrial plant communities," in $\mathrm{CO}_{2}$ and Plants, E. R. Lemon, Ed., pp. 177-222, Westview Press, Boulder, Colo, USA, 1983.

[27] H. A. Torbert, S. A. Prior, G. B. Runion, M. A. Davis, S. G. Pritchard, and H. H. Rogers, "Nitrogen and carbon cycling in a model longleaf pine community as affected by elevated atmospheric $\mathrm{CO}_{2}$," Environmental Management, vol. 33, supplement 1, pp. S132-S138, 2004. 


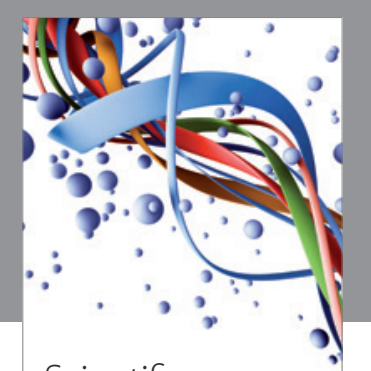

Scientifica
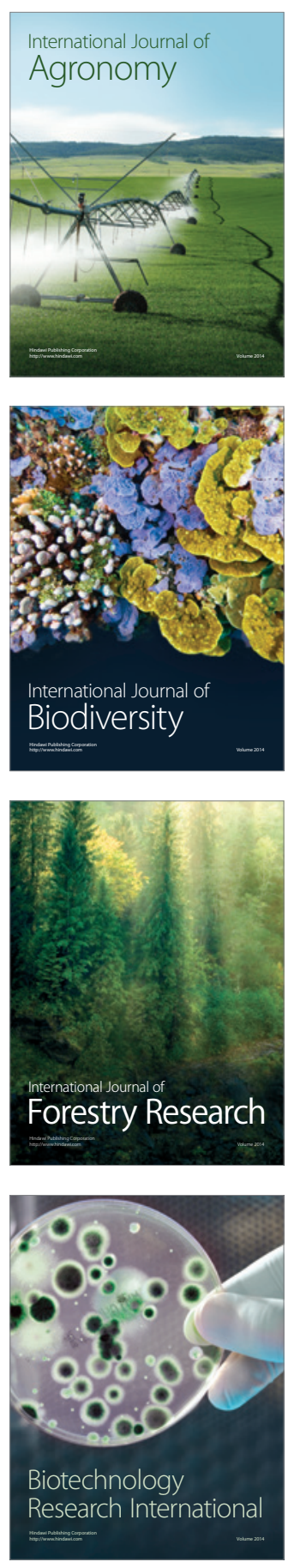
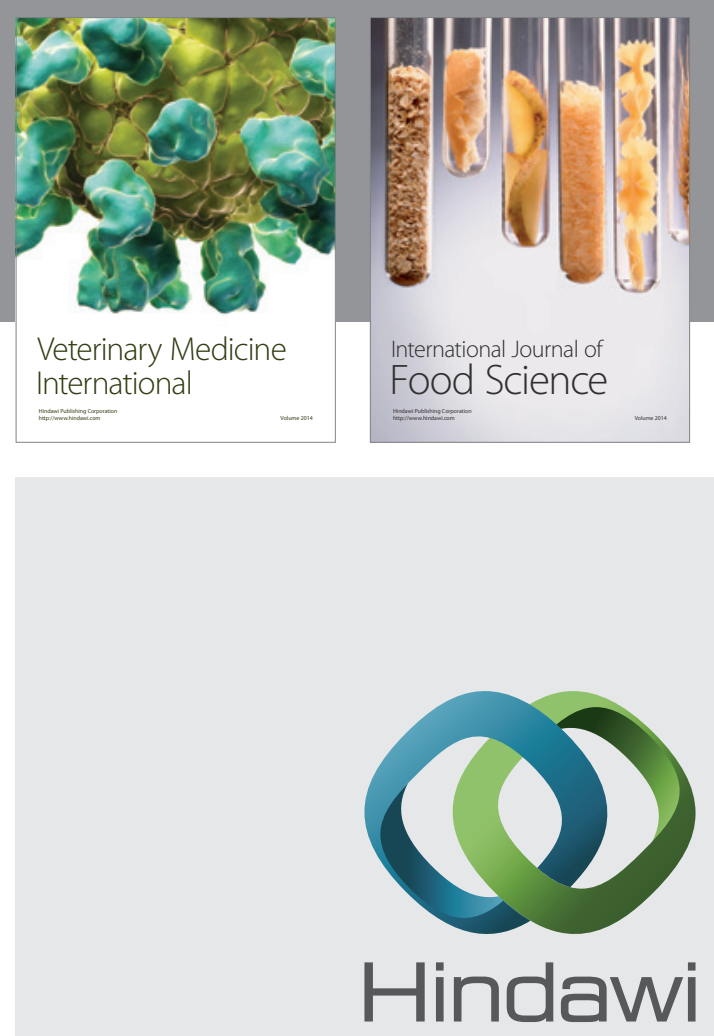

Submit your manuscripts at

http://www.hindawi.com
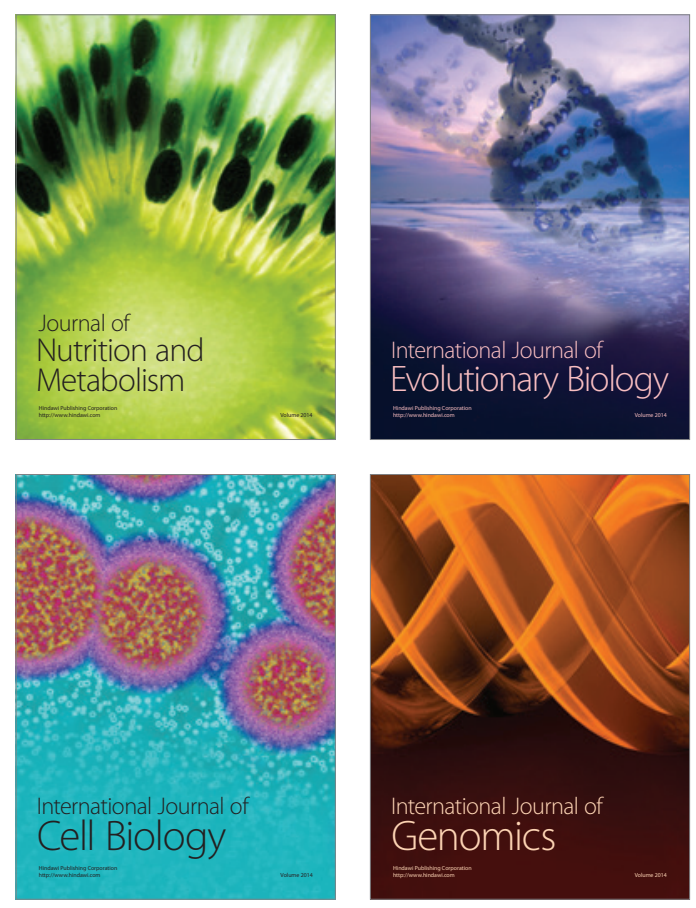
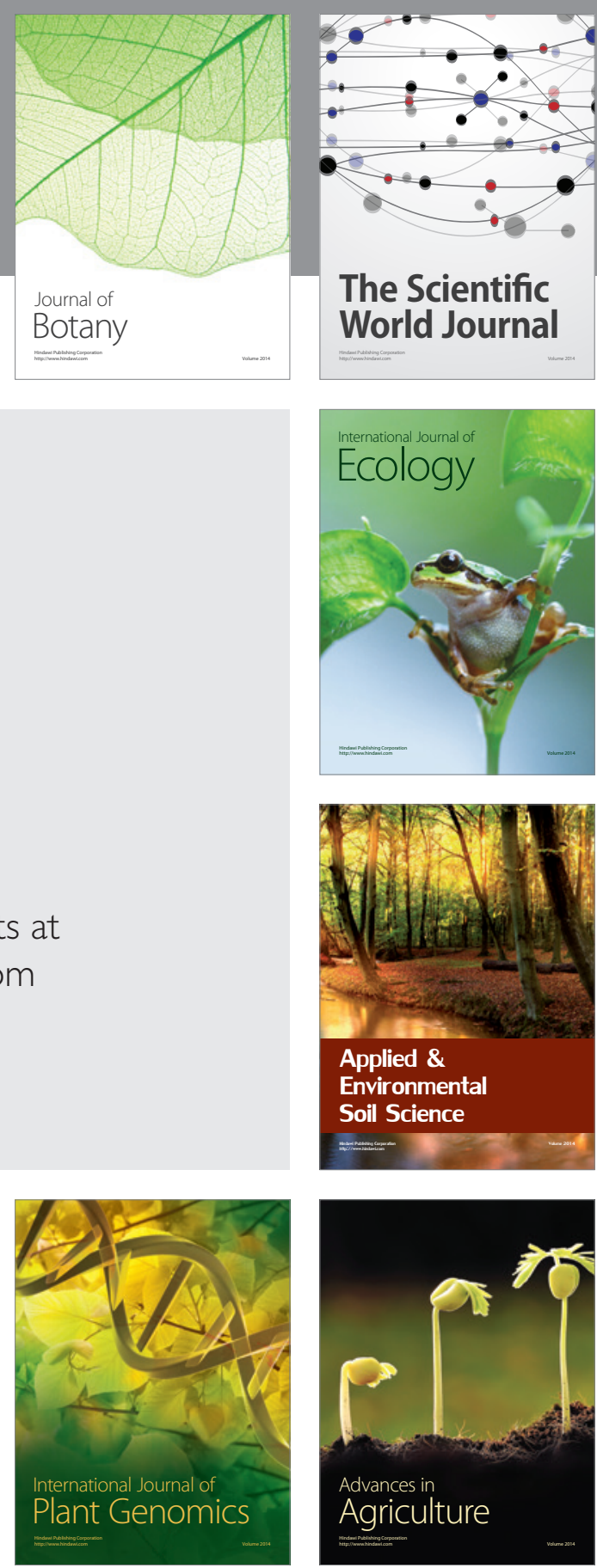

The Scientific World Journal
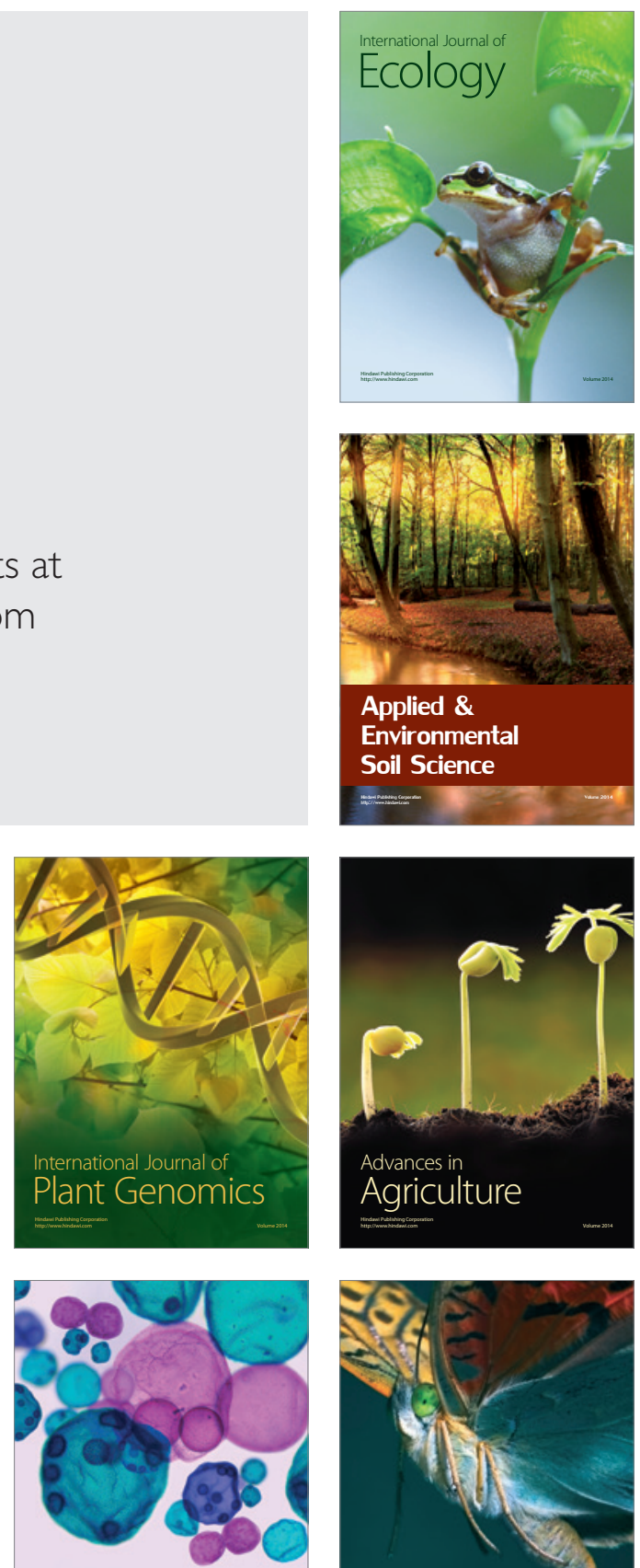

International Journal of Microbiology

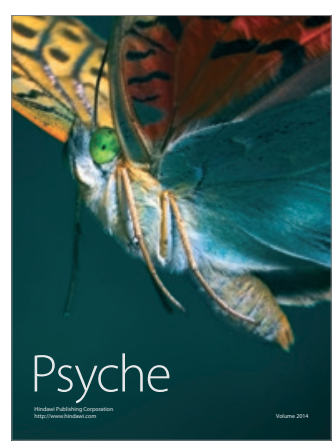

